\title{
Universiteit
}

Leiden

The Netherlands

\section{Beyond legibility: violence, conflict and development in a South African township}

Bähre, E.

\section{Citation}

Bähre, E. (2007). Beyond legibility: violence, conflict and development in a South African township. African Studies, 66(1), 79-102. doi:10.1080/00020180701275956

Version: $\quad$ Not Applicable (or Unknown)

License: $\quad$ Leiden University Non-exclusive license

Downloaded from: https://hdl.handle.net/1887/121949

Note: To cite this publication please use the final published version (if applicable). 


\section{Beyond Legibility: Violence, Conflict and Development in a South African Township}

\section{Erik Bähre}

To cite this article: Erik Bähre (2007) Beyond Legibility: Violence, Conflict and Development in a South African Township , African Studies, 66:1, 79-102, DOI: 10.1080/00020180701275956

To link to this article: https://doi.org/10.1080/00020180701275956

册 Published online: 01 Aug 2007.

Submit your article to this journal

LII Article views: 332

Q View related articles ¿

4 Citing articles: 6 View citing articles 진 


\section{Beyond Legibility: Violence, Conflict and Development in a South African Township ${ }^{1}$}

\section{Erik Bähre}

\section{University of Amsterdam}

\section{Power and development}

While I was trying to make sense of my fieldwork experiences in the townships and squatter camps of Cape Town, South Africa, I read Scott's Seeing Like a State (1998) and Ferguson's Anti-Politics Machine (1990). The puzzling, contradictory and complex phenomena of development suddenly made sense. One could clearly see how, as argued by Scott (1998), the state-driven Reconstruction and Development Programme (RDP) in South Africa was simplifying the physical and social landscape of African Xhosa-speaking residents in Cape Town. In particular, Scott's concept of 'legibility' seemed aptly to describe the development process. The post-apartheid government tried to make complex social and political life more legible through taxation, regulation, and the administrative ordering of the landscape. This is particularly apparent when one examines the way in which state-driven development transformed the area of Indawo Yoxolo in Cape Town, the main site of my research.

Before the development project began in 1995, Indawo Yoxolo was still an informal settlement consisting of a few dozen shacks that only very recently had been built between a large coloured township to the south and an African township to the north. These few shacks were scattered between the bushes, a muddy path pretended to be a road, the bushes served as toilets, and there was no electricity or water. Although Indawo Yoxolo was located in the middle of the Cape Metropolitan area with an estimated three million inhabitants it was quite difficult to find, it was not yet on any roadmap and, referring to Scott's (1998) theory on the failure of development, 'illegible'.

However, the development project had a profound impact. Adjacent to these shacks, construction workers had cleared bushes and levelled the ground with heavy machinery. They were transforming the illegal squatter settlement of Indawo Yoxolo into a formal township with a grid-like structure complete with electricity, toilets, water, streetlights, schools, public telephones, bus stops, taxiranks, sports fields, and plots for poor people to live on. Instead of a disorderly collection of shacks, these construction companies were ordering the environment 
according to the principles of legibility with straight roads and square plots with numbers that helped to identify its future residents (see Photo 1). In 1997 and 1998 , the period during which most of the fieldwork for this article was undertaken, a large formal township with uniform houses emerged while only a small part of Indawo Yoxolo consisted of disorderly placed shacks.

In a social sense too, the state-driven RDP was simplifying and ordering complex social and political realities according to the principles laid out by Scott (1998). The RDP had installed community leaders who carried out the project on a local level (see also Bähre 2001). ${ }^{2}$ Moreover, legibility was inherent in the registration of applicants for housing grants, which appeared to be central to post-apartheid citizenship. During apartheid most Africans were denied citizenship and confined to live in impoverished Bantustans. The RDP was part of recognising Africans as citizens of a democratic South Africa and many Africans left the impoverished Bantustans of Ciskei and Transkei for Cape Town in search of employment. The RDP incorporated some of them into bureaucratic machinery that registered their identities, gave each a case number, and with the aid of the community leaders ranked them on the waiting list for housing grants. Social engineering and simplification was written all over the RDP and notwithstanding the success of the project, it at least managed to strengthen the power of the state as argued by Ferguson (1990), and was a clear project of legibility as argued by Scott (1998). ${ }^{3}$

The Foucauldian view on power and development that is central to the analysis by Ferguson (1990) in particular, also appeals to the residents' experience of

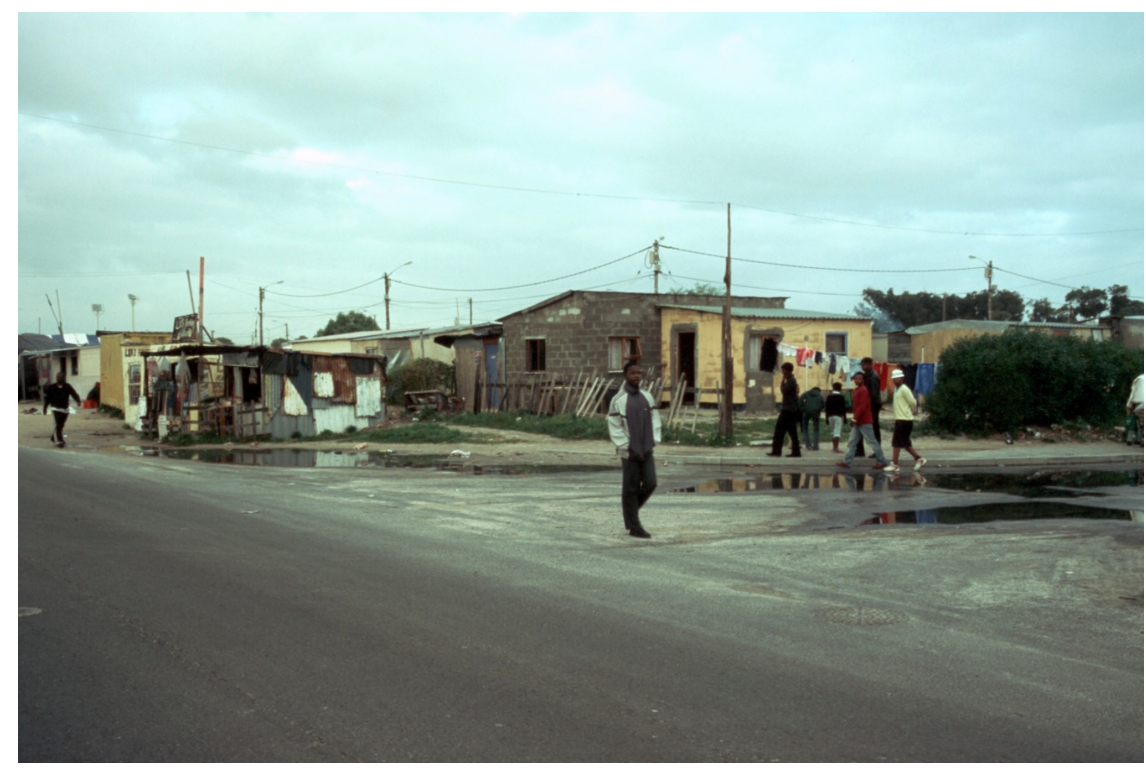

Photo 1. Indawo Yoxolo - Legibility through housing development 
powerlessness. ${ }^{4}$ This study will reveal how residents of Indawo Yoxolo suffered the consequences of development and were unable to successfully address their concerns and worries to the appropriate authorities. Powerlessness also characterised my own experience with development in Indawo Yoxolo. Development was hurting people, even providing reasons for murdering some residents, but I was unable to successfully convey this to development planners and project managers so they could change the way in which the project was being carried out (see Bähre 2005). ${ }^{5}$

Notwithstanding the attractions of a Foucaldian approach to state-driven development, particularly the way in which legibility is pivotal to development and its failure, it became increasingly problematic for an intimate understanding of the problems occurring in Indawo Yoxolo. The relative failure or success of the project depended largely on local conflicts and violence. These conflicts and the violence cannot be understood as resistance to a democratic state, but were nonetheless vital to the development project. Anthropologists have too readily categorised social practices as resistance, thus glossing over many of the other strategies, emotions, ambiguities, changing coalitions and insecurities (see Ortner 1995; contributions in Abbink, De Bruijn and Van Walraven 2003). Ortner rightly warns us that 'The impulse to sanitize the internal politics of the dominated must be understood as fundamentally romantic' (1995:179).

In Indawo Yoxolo, there were many fights over political authority, entitlement, legitimacy of policies and projects, jobs, plots, and so on. This study argues that, in order to understand the relative success or failure of development, one needs to go beyond legibility and examine development as an arena of contestation over scarce resources, ideological justifications, as well as political security. ${ }^{6}$ The case study of Indawo Yoxolo reveals that, instead of the establishment of more or less hegemonic power of the state over its citizens, state development led to fierce and violent conflicts in which mafia-style leaders, rivalling political factions, as well as protesting residents, tried to take charge of the development project.

\section{The project}

With the release of Nelson Mandela in 1990 and the first democratic elections in April 1994, many hoped for a drastic change for the better. Although many South Africans realised the African National Congress (ANC) could not overcome the legacy of apartheid within a few years, they nevertheless expected that the political changes would lead to redistribution. The post-apartheid government tried to decrease poverty by redistributing resources through development. A pivotal role was envisioned for the national RDP (ANC 1994). Poverty stricken Africans and, to a lesser extent coloureds, needed improved communal facilities, such as sanitation, roads, better policing, as well as health care. 
One of the most prominent features of the RDP was a housing grant for the poor and it was planned that between 1994 and 1999 one million low-cost houses would be built. According to income, housing subsidies of up to R15,000 were made available. $^{7}$ This subsidy was not distributed directly to the applicant in cash. Instead, private sector building companies and, in some instances, nongovernmental organisations (NGOs) were contracted to build roads, plots, electricity connections, sewage systems, toilets, and other facilities. If applicants were eligible for a grant they were granted ownership of such a plot. ${ }^{8}$

The Development Planning Committee (DPC) carried out most of the development projects in Cape Town. When the apartheid regime began crumbling, political organisations, grassroots organisations and government bodies in Cape Town established the DPC, consisting of different political parties, government institutions and community-based organisations. The DPC was later incorporated into the national RDP. ${ }^{9}$ The DPC's aspiration for Cape Town was to develop and upgrade 34,500 sites and improve the housing situation of more than 35,000 poor black families within five years. Residents from twenty-one informal settlements, eight areas of backyard shack dwellers, and residents of three hostels had to benefit from this project and another 6,200 coloured families who were on waiting lists for housing could get access to the project (DPC 1994:8). ${ }^{10}$

The ANC incorporated an active approach towards democratisation into their development plans (ANC 1994:119-135). Development policy was explicitly political: it had to contribute to democracy and empowerment through community participation (see also Niksic 2004). During this period, around 1997/98, local government was still regarded as problematic for achieving community participation. The legacy of apartheid had left local government understaffed and in shambles with few resources. Local government not only had the difficult task of transforming from an apartheid-style to a democratic institution, it also suffered from a lack of legitimacy due to the collaboration of councils with the apartheid state. Therefore, community participation had to be achieved through other local community based organisations, particularly those that had resisted the apartheid state in the past. These neighbourhood organisations known as 'civics' had organised impressive boycotts, stayaways and protest marches against the state (Jacobs 1992:23-24; Matiwane and Walters 1986:72; Kessel 2000). After the 1994 elections, the role of the protesters against the government changed considerably, which led to their demise (Seekings 1996). Development policy stipulated that civics were vital for a successful implementation of development objectives and had to be incorporated in all stages of development through a locally organised community based RDP forum (Seekings 1992:216). ${ }^{11}$

In Indawo Yoxolo, the RDP forum was known as the project committee and it became a powerful intermediary between the community, the DPC, government agencies, and private construction companies. It had to advise on the implementation of the policy and had a crucial say in establishing priorities in the 
community. The role of the project committee was especially powerful because it was responsible for people's housing applications according to the applicants' household composition, income, and, most importantly, residential history. It was, however, virtually impossible to ascertain how long illegal squatters had lived in a particular area, which made the waiting list extremely vulnerable to fraud. Moreover, the project committee was crucial for the recruitment of labour for the housing projects: at least fifty per cent of the labourers had to be recruited from residents of Indawo Yoxolo. The project committee was in charge of selecting residents and suggesting them to the companies, working in the area, who generally followed their suggestions. ${ }^{12}$

The project committee in charge of development in Indawo Yoxolo was made up of representatives of residents of the illegal squatter camps who were eligible for a plot. Unfortunately, I could not determine exactly which members of the project committee came from which settlement, how exactly they became members of the project committee, or why other residents were not chosen. The violence carried out by the committee and the obscurity of local and provincial politics made it impossible to obtain this information. It was clear, however, that their main stronghold was in the old, unserviced Indawo Yoxolo that I had encountered in 1995, and that they had less support among residents, living in the serviced part of Indawo Yoxolo, who had already received their plots. The residents of the unserviced area were still waiting for their housing grant and therefore were more dependent on the project committee than those living in the serviced areas of Indawo Yoxolo because they were still waiting for their housing grant.

Those who opposed the project committee referred to it as the 'Big Five'. The Big Five refers to the five powerful animals of South Africa's game parks: leopard, lion, elephant, rhino, and buffalo. The adoption of the name Big Five for the project committee emphasised the power and danger of this group. Moreover, the name Big Five reminds one of the big man paradigm (see Thoden van Velzen 1973).

It was not possible for me to come close to the Big Five (Bula, Zantsi, Nqase, Posa, and Mtontsi); they were too dangerous and it was best to avoid them as much as possible. Nqase was known as 'the gun' of the Big Five. He had a reputation as someone who was stupid enough to kill and get caught and of being involved in all kinds of dirty business, even outside of Indawo Yoxolo. He was not reputed to be the brain behind the organisation, but it was popular knowledge that he was willing to murder people. Nqase was a big man of about forty, possibly younger. He was always smartly dressed, carrying a trendy mobile phone, and one could clearly notice the gun bulging from underneath his jacket or sweater. Zantsi was reputedly the most powerful and smartest of the Big Five. A Big Five opponent in Indawo Yoxolo told me that whenever the Big Five resorted to violence, he was 'accidentally' away for a visit to his home in the former homeland of Transkei. Due to my endeavours to stay away from the Big Five, I had 
actually never talked with him and had only seen him in the distance. Bula, the third member of the Big Five, was from Gxuwa (Butterworth), the same place where Gilbert Mabeqa, the leader of the opposition, came from. His reputation was also that of a powerful man who threatened and blackmailed people. The remaining two members of the Big Five, Posa and Mtontsi, were regarded as less powerful. Mtontsi was a small, badly dressed man who, despite his young age, had several teeth missing. He worked frequently for the construction companies in Indawo Yoxolo and could be seen wandering the streets visibly drunk. Posa was almost invisible and hardly ever heard from and I often forgot that he was even a member of the Big Five.

The Big Five controlled the DPC projects, as well as any other initiative in Indawo Yoxolo. These included the building of schools, the appointment of teachers, the distribution of RDP plots to applicants, and even the plans to build speed bumps to slow down traffic. Many schoolteachers supported them and took advantage of this power. They would take children's lunches, forcing them to buy sweets and chicken feet from women - also Big Five supporters - who had their little food stalls on the enclosed school grounds. The Big Five were also responsible for finding local labourers to work for contractors, such as Donald and Gromit and A\&W Construction. Moreover, they cooperated with certain factions of the ANC and, at times, also with other political parties (the National Party (NP) and the United Democratic Movement (UDM)). Their most important power base, however, was as the DPC project committee.

Control over the distribution of resources made the Big Five very powerful and they used violence and intimidation to maintain and exploit their position. Among others they demanded bribes before a plot was allocated to an applicant. Moreover, they promised to make Indawo Yoxolo a better place in return for support. Although the Big Five provided jobs and gave some people political support, they did not present themselves as, nor were they considered to be, guardians of the welfare of the community. Their mafia-style rule was based on intimidation, murder, and corruption, as well as control over the resources of the development projects.

\section{An emerging opposition}

Some of the residents of Indawo Yoxolo who had already received their RDP plots dared to oppose the Big Five. This opposition had no official name, but they sometimes called themselves the 'new committee' because they considered themselves the legitimate successors to the 'old committee'. The opposition wanted to elect new community leaders that represented all residents. Their most prominent leader was Gilbert Mabeqa, a former ANC comrade who had moved with his wife and teenaged daughter from a shack in Guguletu to a plot in Indawo Yoxolo. Because of his central position, I will call this opposition Mabeqa's group. Most of the supporters of Mabeqa's group lived in the serviced part of 
Indawo Yoxolo. Mabeqa, Gxyiza, Constance, Michael, and my research assistant Edith, were among the most active people that opposed the corrupt and violent Big Five. $^{13}$

Mabeqa's group was, just like the Big Five, related to the ANC or, at least, certain factions of the ANC within the local and provincial governments. They had unclear relations with SANCO, but claimed to be the legitimate SANCO committee in Indawo Yoxolo. The Big Five, however, made the same claim. The most important political stronghold of Mabeqa's group was Councillor Gqoli. In May 1996 Councillor Gqoli had been the only candidate for the local government elections for ward X of the Central Substructure, which comprised of Indawo Yoxolo and two other nearby squatter camps. ${ }^{14}$

The serviced section of Indawo Yoxolo with paved streets, plots and facilities was part of ward Z, which also included adjacent serviced townships. The serviced part of Indawo Yoxolo did not fall under Councillor Gqoli's ward but under ward Z, whose councillors were unknown to the residents of Indawo Yoxolo. Because the councillors of ward $\mathrm{Z}$ were unknown, and because Indawo Yoxolo was divided between two wards (the developed part of ward $X$ and the squatter camp of ward Z), Mabeqa's group promoted Councillor Gqoli as the legitimate representative of ward $\mathrm{X}$ and $\mathrm{Z}$.

Councillor Gqoli cooperated with Mabeqa's group because he was concerned about the violence in Indawo Yoxolo and probably also because the RDP structure further undermined his authority. After all, during this period the distinct RDP structure with its distinct project committee was meant to sidestep local government. Local government gained little from the resources that the state provided through development. The Big Five did not acknowledge Councillor Gqoli as the legitimate councillor. Instead, they supported other councillors from the illegal squatter camps where they had lived previously.

\section{Private parties}

Private sector companies were pivotal to the implementation of development. ${ }^{15}$ The government not only gave tenders to construction companies to build the physical infrastructure, but also to private sector companies to manage the project on a day-to-day basis. The development projects were coordinated by Future Dwelling Ltd. in Indawo Yoxolo. It managed the relations with the private sector, the community, and diverse government institutions such as the Department of Education. Moreover, it subcontracted construction work to local companies.

In 1996 Future Dwelling must already have been aware of at least some of the problems the project committee was causing in Indawo Yoxolo. In that year, Future Dwelling organised a workshop with participants of the RDP to discuss the illegal selling of plots. This workshop did not stop corruption and applicants told me they 
had to pay the Big Five bribes of up to R1,200 - for most residents more than a month's income - to be registered on the housing list. Those that were unable or unwilling to pay such a large sum of money were confined to living in the part of Indawo Yoxolo that was still a squatter camp: the Big Five only allowed them to live on a plot after they had paid a bribe. Within days of starting fieldwork in Indawo Yoxolo in September 1997, a resident of the squatter camp of Indawo Yoxolo told me about the problems he had with the Big Five. Just a few nights earlier he had been shot at, allegedly by one of the Big Five members. He took me to his shack and showed me the window that was pierced by a bullet hole. He had been sleeping and he said he counted himself lucky to still be alive. This, he explained, had happened because he refused to bribe the Big Five in return for an RDP plot.

The opposition to the Big Five had made numerous attempts to challenge the relationship between the Big Five and Future Dwelling. They called meetings with Future Dwelling as well as with other development agencies. This, however, was always unsuccessful. Future Dwelling generally failed to attend the meetings, but even when they were present it made little difference. In November 1997 Mabeqa and other opponents of the Big Five finally managed to meet with the director of Future Dwelling to discuss the violence and corruption in Indawo Yoxolo. There were no Big Five supporters present and, therefore, I could easily join the meeting. The Future Dwelling director was unhappy about this meeting, but the presence of the residents of Indawo Yoxolo, and the support of their community leaders, forced him to attend. They told the director about the problems they had with the DPC's local project committee, i.e. the Big Five, and with Gwayi, the Indawo Yoxolo liaison officer. They repeated the allegations, which they had expressed earlier at a local town council meeting, that the liaison officer of Future Dwelling had sided with the Big Five and was also involved in corruption. They held Future Dwelling responsible for supporting the Big Five. Instead of challenging corruption and violence, Future Dwelling was supporting the Big Five through their cooperation with their liaison officer. They pointed out that the Big Five had never been properly elected and failed to represent the many new residents of Indawo Yoxolo. They also told the director that Mhloma, from the Department of Education, persistently ignored Mabeqa's group and continued to cooperate with the Big Five.

The liaison officer responded that Future Dwelling was not going to take any action until a large ANC investigation into the housing and the RDP issues in the Cape Metropolitan Area were finalised. The director added:

Things have changed in Indawo Yoxolo since we started. All political groups have to be included which represent the whole community. It has to be an inclusive community committee and should be elected. Then we have an accredited RDP forum in Indawo Yoxolo. It must include the entire community. 
Mabeqa asked the director how they could be expected to cooperate with people who had threatened and attempted to kill them? The director, however, kept repeating his 'formula' that the project committee had to be inclusive and continued to ignore the political problems in Indawo Yoxolo. ${ }^{16}$

The director refused to take any action concerning the allegations of corruption put to his liaison officer and said: 'One can't change people's jobs based on some rumours.' However, he did promise to replace the liaison officer working in Indawo Yoxolo. Later some residents complained to me that this did not have the desired effect: the new liaison officer relied heavily on the previous liaison officer's advice, and she also worked with the Big Five and ignored Mabeqa's group. The ongoing support of the Big Five eventually led to rumours that Future Dwelling, including its director, were also involved in corruption.

Later, in June 1998, Future Dwelling warned against the unauthorised collection of money and distribution of sites in their freely distributed bulletin. It also gave a telephone number of the project facilitator, whose name was not mentioned, for further queries. The bulletin caused a stir in Indawo Yoxolo as many residents suspected that the unnamed facilitator was the councillor who had cooperated with the Big Five before. The pamphlet was a trap to track down opponents. To my knowledge, nobody dared to phone Future Dwelling and tell them about their experiences with corruption.

The Big Five did not like the pamphlet at all. To me this suggested that it was not a trap. But in such a politically charged and tense situation it became difficult to distinguish the truth from paranoid interpretations. Eunice, one of the residents of Indawo Yoxolo, told me that she had helped to distribute the pamphlets in the neighbourhood. When the Big Five found out they discussed what to do with Eunice. They were in doubt and later told her: Some were in favour of shooting you, while others felt that it was more appropriate to burn you alive. But one of them convinced the others that it was better to talk with Eunice first so she could offer a defence. Eunice was scared for her life and told them that the pamphlets came from Ma Ntshona. Ma Ntshona was a known Big Five supporter and liaison officer for one of the construction companies. Because she supported the Big Five, Eunice thought they would not object. The Big Five decided to leave her alone and gave Ma Ntshona a R150 fine. Eunice was very relieved and felt that Ma Ntshona received only a small punishment in order not to alienate her. Ma Ntshona knew a lot about the Big Five and could easily go to the police should they turn against her. This incident reveals that the relationship between the Big Five and Future Dwelling was not as cosy and intimate as the opponents of the Big Five felt it was. Nonetheless, the fact that key objectives of the development process, such as empowerment and democracy, were not met did not lead to any changes by Future Dwelling. Thus, Future Dwelling provided the Big Five with development resources to become men of influence. The main challenge for the Big Five's opponents was to skew the distribution of resources that were so 
central to the Big Five, as well as the political security that the Big Five received from Future Dwelling, the government, and the ANC.

\section{ANC: volatile relations}

At the end of 1997 the political situation in Indawo Yoxolo changed drastically. This had major consequences for the development project. In October 1997, the ANC in the Western Cape established a Commission of Inquiry into the allegations of corruption and violence by the Big Five. ${ }^{17}$ The Commission of Inquiry recorded twenty-seven testimonies by residents of Indawo Yoxolo concerning intimidation, violence, and corruption. They informed the Commission about having to bribe Big Five members in exchange for plots to which they were already entitled, and explained how the Big Five seized plots from legitimate owners in order to sell them to people who did not qualify for a RDP grant. They also complained about the violence. One plaintiff stated that he was beaten with the butt of a firearm while another man had been shot. He did not see who fired the gun but one of the Big Five members had told him this. Another man testified that one of the Big Five had threatened him at gunpoint.

The Commission of Inquiry gave the Big Five members the opportunity to respond to these allegations. The Big Five blamed Councillor Gqoli for the problems in Indawo Yoxolo. They were upset that he had openly supported Mabeqa's faction and felt that, although he was the councillor, he had no right to interfere in Indawo Yoxolo. To the allegations of bribery, they replied that they had collected a small amount of money from residents (R50 per household) to cover administrative expenses. They denied that they had been selling houses and claimed that some residents did not want their plots and preferred money instead, so they had only acted as intermediaries between sellers and prospective buyers.

The Commission of Inquiry drafted a report advising the ANC in the Western Cape on further actions. The Commission concluded that comrades were frequently accused of crimes without being guilty of misbehaviour. They stated that it was probably true that the Big Five had been selling plots, as this was known to happen in many informal settlements in the Western Cape, such as Crossroads. The twenty-seven testimonies gave the Commission sufficient evidence that four comrades were involved in the illegal selling of plots in Indawo Yoxolo, even during the period in which the Commission of Inquiry was in session.

The Commission furthermore concluded that the scarce availability of resources contributed to the conflicts. They argued that Indawo Yoxolo was incorporated in a greater RDP structure, but needed a separate RDP structure. They had noticed that some felt that Indawo Yoxolo was neglected and was not receiving its share and that the adjacent African township was favoured. According to the 
Commission, the ward councillor and ANC member Gqoli had failed to recognise the tensions between Indawo Yoxolo and the adjacent African township and should not have interfered. Thus, the report stated, Gqoli had sided with the opponents of the project committee (the Big Five) and thus heightened the divisions in Indawo Yoxolo. Another factor that, according to the Commission of Inquiry, contributed to the conflict was that the DPC had started to give money at meetings as an incentive to attend. As a result, the project committee began monopolising the meetings so they could distribute the money only among their supporters.

The Commission of Inquiry recommended the ANC of the Western Cape to take action against some of the Big Five. The accusations of the residents focused on Nqase and Zantsi in particular. They were accused of illegally selling plots; tampering with the waiting list; 'selling' an occupied house; theft; harassment; and intimidation at gunpoint. The recommendation was that these two had to be expelled from the ANC for six months. Another Big Five member, Mtontsi had to receive a stern warning for harassment, beatings with a firearm, and the illegal sale of houses. The most severe recommendation concerned Zantsi, who was to be expelled from the ANC permanently. Zantsi had, according to the twenty-seven testimonies, bribed people, illegally sold their plots, and attempted to kill one of the complainants.

Although the Commission did not question the allegations against Zantsi, they were not given as the reason for their recommendation. Instead, they advised the provincial ANC to expel him because of his lack of party loyalty:

\footnotetext{
Reason for this stern action [expulsion from the ANC] are [sic] that he has really acted in a devious manner, like leading a march to the ANC office and organizing the radio to come thus ridiculing and bringing the name of the organization in disrepute. Also there are strong rumours and information which we have investigated and found to be true of him inciting a mass meeting in Indawo Yoxolo for people to join the NP or Holomisa (UDM). (Commission of Inquiry, 22 October 1997)
}

Because some of the Big Five held key positions within SANCO, the Commission of Inquiry proposed that SANCO be informed about the problems in Indawo Yoxolo. They also noted that participation by these comrades in the RDP had to be re-evaluated and that people who wished to take legal action should be encouraged to do so. The Commission of Inquiry did not report the crimes to the police. The ANC in the Western Cape enforced the Commission's recommendations. However, after one year, Zantsi was re-admitted to the ANC, despite the fact that he was supposed to be expelled for life. For the commission the criminal and violent activities of the Big Five appeared to be less important than party loyalty. One of the recommendations of the Commission was that a proper ANC branch be established in Indawo Yoxolo, which was absent up to then. Thus, the ANC gave political security, which is one of the parameters of the big men paradigm, to the Big Five in return for their political loyalty. 
Although the Commission acknowledged the existence of corrupt practices and abuse of power, their measures against members of the Big Five were inspired by party loyalty. The ANC wanted other political parties to be kept out of Indawo Yoxolo, an ANC branch in the area, a stop to relations between the Big Five and SANCO, the removal of the councillor from the area, and the Big Five's proof of loyalty to the party. This, in my view, reveals how difficult it was for the provincial ANC to manage local political groups such as the Big Five. The measures that they proposed emphasised party loyalty and control over a new community. Instead of state expansion through development, the relationship between the project committee and the ANC was much more precarious and characterised by uneasy cooperation.

\section{A divided government}

Although the position of the Big Five was still secure, the Commission of Inquiry did lead to tensions between the Big Five and the ANC. Moreover, the national and provincial political landscape started to change, which strongly influenced local political alliances.

The 1994 elections had resulted in a tremendous victory for the ANC. The ANC secured the majority for the national government and, together with the NP and the Inkatha Freedom Party (IFP), formed the Government of National Unity. The Government of National Unity, with Nelson Mandela as president and NP leader F.W. De Klerk as vice-president, emphasised that the transition had to be peaceful, and that the new South Africa was inclusive, which meant that minority parties also had a voice. The elections in the Western Cape were held simultaneously with the national government elections. But in this province the ANC did not get the majority and instead the NP became the most powerful party of the province. This was largely due to the many coloureds living in Cape Town who en-masse voted for the NP. They were concerned that their relative advantage over Africans would be lost if the ANC came to power. The Western Cape was exceptional because it formed a provincial government of unity with a NP majority and an ANC minority.

Two years later, in June 1996, the NP left the Government of National Unity. They felt sidelined by the ANC and argued that democracy would benefit from a strong opposition party. Strategically, it also seemed better for the NP to become an opposition party in preparation for the upcoming national elections. ${ }^{18}$ The break between the ANC and the NP in the national government was followed by a similar move in the Western Cape. The ANC declared that it could no longer cooperate with the NP and that they had been completely powerless within the provincial government. There was no unity and the NP was said to consistently ignore the issues that the ANC put on the agenda. With the next elections in mind, the ANC preferred to take up the role of opposition party. It withdrew from the ministerial posts in the provincial government and opposed the NP from 
the benches of provincial parliament. On 20 January 1998, the NP voted in the new provincial ministry, which consisted only of white and coloured men and excluded the ANC. On a national level, the ANC could do without the political support of a severely weakened NP, and on a provincial level the NP could do without an ANC minority. ${ }^{19}$

Most residents of Indawo Yoxolo did not want to comment on politics, but the few who did felt that in the Western Cape the NP was now completely in charge of all government activities in the province, including the post-apartheid development process. After it left provincial government, the ANC was regarded as incapable of providing development for Africans. Some told me they wondered how the ANC of the Western Cape could secure money and services for Africans now that they were forced into opposition. Some even suggested that it was better to join the NP, and an ANC comrade told me: 'It is better to be oppressed by whites than by your own people.' Such remarks, however, were few and far between. Mostly residents tried to avoid political issues, in the same way they tried to avoid them during apartheid.

The Big Five, who relied on a precarious relationship with the ANC for political security, were also affected. In their quest for continuous political support and control over development resources they approached the NP councillors of the adjacent coloured township Mountain View. For its part, Mountain View's NP was eager to embrace the community leaders of Indawo Yoxolo: African support would do the party image good and could attract more votes in the upcoming provincial elections. The Big Five made sure not to alienate themselves from the ANC too much. Although some had been expelled from the ANC they carefully explored the relationship with the NP while keeping an eye on the ANC. Clearly, ideological concerns did not appear to be a major consideration for these political alliances.

Three weeks after the provincial government was installed without the ANC, the conflict in Indawo Yoxolo dramatically worsened. One evening when Mabeqa and his friend Michael were walking around in Indawo Yoxolo, Nqase and Bula approached them. Nqase shot Mabeqa twice, once in the back and once in the back of his head. Then Bula shot Nqase in his leg while Michael ran for his life. Apparently the reason Bula shot Nqase in his leg was that later, in court, they could claim that Nqase had killed Mabeqa in order to defend himself and Bula. This argument was later used in court. After some time, however, Nqase was found guilty for the murder of Mabeqa and consequently served a short prison sentence.

The days that followed the murder of Mabeqa, members of the Big Five or known supporters visited many residents who had publicly opposed the Big Five at their homes. During these visits, they were intimidated and told that they would be next on the hit list and some would proudly state that their leader was now taken care of. Within a few days, virtually all the known political opponents of the Big Five fled 
Indawo Yoxolo and went into hiding. The Big Five were brimming with confidence and were more powerful than ever. Although some opponents had appealed to the police for security measures, nothing came of it. As usual, there were never any police officers in Indawo Yoxolo.

On the surface, everything seemed to be back to normal in Indawo Yoxolo. I was astonished to see how little visible impact the murder of the leader of the opposition to the Big Five had had on most people. A prominent resident was killed, but that only took a few minutes and only a few people had to flee Indawo Yoxolo. It was not reported in any newspaper or on the radio. Although the political consequences of this murder were significant, most residents tried to mind their own business. They were too scared and intimidated to even talk about what happened and this denial of violence seemed to be a vital strategy to manage daily life.

Within the next few days it became clear that the Big Five did not hesitate to further cash in on their powerful position. The brother of one of the Big Five members had presented residents of Indawo Yoxolo with a contract that allowed a construction company to use the remains of their subsidies to build little one-roomed houses on their plots. Many people wanted to keep the remains of their subsidies and join an NGO and save money for a better structure. But out of fear for the Big Five many did sign the contract. They were not given a copy of the contract, nor did they dare complain about the terrible 'houses' that were built.

Mabeqa's murder led to a court case against Nqase. In addition to the murder charge, the police found two boxes with illegal firearms at Nqase's house and there were further charges related to the murders of one or more people in the nearby township of Crossroads. Despite the fact that there were five cases in total brought against him, he was nonetheless released on bail. Just a few days after the murder, he was strolling around Indawo Yoxolo, chatting to everyone on the streets. When I finished my fieldwork in December 1998, he had not yet been convicted. However, I heard from Mabeqa's wife that he was finally imprisoned in 1999, more than a year after the murder. By the end of the same year, however, he was back on the streets of Indawo Yoxolo.

The political insecurity with which the Big Five were confronted, combined with a lack of clarity on the way in which the resources of development were to be distributed, led to an increase in violence. The Big Five were now more powerful than ever and continued their work as the DPC project committee while the murder of Mabeqa confirmed their authority over the people in Indawo Yoxolo. The failure to establish democracy and empowerment through state-driven development projects such as the RDP can only be understood if these national and provincial political frictions are recognised. Clearly, there is no unified state with a unified development agenda. Instead, national and provincial political dynamics, as well as the ANC's Commission of Inquiry, had been threats to the Big Five. 
The 'flirtation' with the NP, as well as the murder of Mabeqa successfully reinstated their position of power in times of temporary political insecurity.

\section{A new faction emerges}

In the following months, the Big Five and their supporters killed three more residents of Indawo Yoxolo. One was known to be an opponent, while another was the younger brother of an opponent. They shot the latter through the corrugated iron wall of his shack because they mistook him for his older brother. Another Big Five supporter kicked a twelve-year-old child to death in retaliation for the audiocassettes the child had allegedly stolen. The parents were too scared to report the murder to the police. Michael, who witnessed the murder of Mabeqa, was also shot at. His story was confusing and inconsistent. He told me that he was taken by surprise late at night when police officers sent by the Big Five entered his shack. They shot him in the hand, the stomach, and his leg. He told me that he had been unarmed, but because he was first shot in his hand it seemed possible that he had either held a weapon or was reaching for one. Half a year after the shooting he was still a crippled shadow of the strong and confident man he once was.

The murder of Mabeqa and other opponents led to more political changes in Indawo Yoxolo in which 'Shooter' - a telling nickname - played a key role. Shooter claimed to represent SANCO in Indawo Yoxolo. His position had always been unclear and people wondered to what extent he opposed the Big Five or whether he was actually an ally. After Mabeqa's murder Shooter had got into the habit of walking through the neighbourhood at three o'clock at night, while firing his gun. This was his routine, sometimes for weeks in a row, which scared the residents tremendously, not least the anthropologist amongst them.

Shooter and Zantsi, the leader of the Big Five, were going to have elections in the community to establish a SANCO interim committee. Although the elections were held in a public place in Indawo Yoxolo it was regarded as a space controlled by the Big Five: They usually had their community meetings under these same trees. The location and the central role of Zantsi and Shooter in the elections meant that it was mainly Big Five supporters who were present at the election. The vast majority of residents were uninterested or too scared to oppose Shooter and Zantsi and did not attend the meeting. At this 'election', Shooter and Zantsi elected themselves: Shooter became the chairperson and Zantsi a board member to SANCO.

Shortly after the elections, a long lasting dispute over housing grants and the allocation of plots emerged between Shooter and Zantsi. Some residents who were unable or unwilling to bribe the Big Five still lived in the squatter settlement and had yet to move to their new plots. Future Dwelling still continued with 
threats to evict them. Quite soon after the elections Zantsi and Shooter started to argue about the exact number of people living in the squatter settlement. According to Zantsi, there were 312 households who qualified for a plot on the site in question. Shooter argued that there were 424 households, because this was the number of people officially registered on the DPC's housing list, a list controlled by the Big Five. Zantsi had made an actual count with members of the city council's Housing Committee. They had counted 312 households. Shooter questioned the outcome of this count because a councillor known to be loyal to Zantsi chaired the Housing Committee that organised the count. The discrepancy of 112 households fed allegations of corruption against the Big Five. They were rumoured to have put extra people on the housing list in return for bribes, and to have sold plots to people who were not even registered.

The dispute between Shooter and Zantsi was not only because of this incident. Again, national and provincial political processes appeared to influence local political relationships. In September 1997, Bantu Holomisa and Roelf Meyer established a new political party: the UDM. Bantu Holomisa headed the Transkei under the apartheid regime and, after the 1994 elections, he became the national deputy minister of environmental affairs. He was expelled from government and the ANC and the general opinion was that this was because he had complained that the ANC did not adequately address the problem of corrupt party members. Roelf Meyer, a young NP politician who had played a major role in the 1992-93 negotiations that led to the abolishment of apartheid, formed an alliance with him. Meyer felt increasingly dissatisfied with the NP's inability to reform and attract black voters. Together they presented the UDM as an alternative party, which was not based on race, and which, unlike the NP and the ANC, was not embedded in the history of apartheid. It was expected that their main stronghold would be in the Eastern Cape province, which now includes the Transkei homeland where Bantu Holomisa had been the leader.

Virtually all African migrants to Cape Town were Xhosa and came from the Eastern Cape. The UDM, therefore, tried to gain support in Cape Town for the 1999 local government elections. Because of the large support that the NP had received in this region, the elections in this province were regarded as more crucial than in most other provinces where it was clear that the ANC was going to win. The UDM had approached Shooter to establish a UDM branch in Indawo Yoxolo. If the UDM did well in the elections, new political opportunities could emerge, which prompted Shooter to turn his back on the Big Five. Some, however, regarded the opposition by the UDM as a big hoax and expressed their fear that secretly the Big Five and Shooter were still allies. They argued that no matter if one voted for the ANC or the UDM, one would keep the same people in power.

Although Zantsi was expelled from the ANC for life for his lack of party loyalty he was re-admitted at the end of 1998. With the elections coming closer the ANC seemed to prefer to keep Zantsi among their ranks, as a powerful leader in 
Indawo Yoxolo. Moreover, the ANC never appeared particularly enthusiastic to punish Zantsi for his crimes in Indawo Yoxolo. Immediately, the Big Five turned its back on the coloured NP councillor in Mountain View. Although there was a court case in process against Nqase, as well as against other Big Five members, the Big Five remained the most powerful political group. The local government elections in 1999 were quite favourable to the Big Five. The ANC had won the ward that included Indawo Yoxolo and Zantsi, the only candidate for Indawo Yoxolo, was now its councillor.

\section{Insecure power}

There were local government elections again in 2006. Zantsi was the ANC candidate but residents wondered if he was going to win as his popularity had decreased and the development project was nearing its end. However, the expectation of development remained an important source of power and income for Zantsi. The rumour spread that new housing developments were going to take place to the east of Indawo Yoxolo, and Zantsi surely contributed to it. Those people living in the shacks in this area could claim a housing grant in the near future. Consequently, this small squatter settlement rapidly expanded (see Photo 2). Even families that already had an RDP plot in Indawo Yoxolo were building shacks in this area. Mostly, they would rent it out or use it for business purposes, such as running a shebeen (illegal beer-drinking place). They hoped to get access to a second RDP house without having to live in this very unpopular (because of the violence and lack of facilities) squatter settlement. Zantsi largely controlled this area: In order to erect a shack one had to pay him a bribe, mostly between R500 and R1,000.

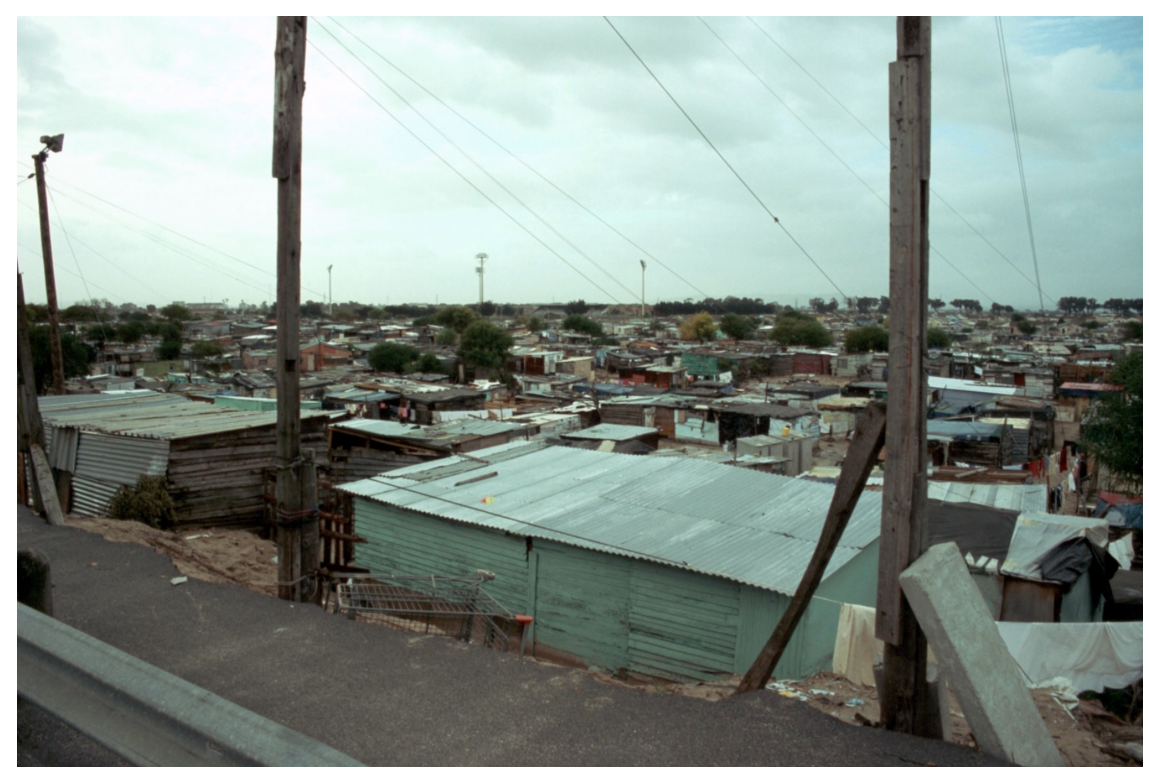

Photo 2. A new squatter settlement emerges on the outskirts of Indawo Yoxolo 
Although the expectation of development gave Zantsi some power and new financial resources, it appeared that, with the finalisation of the development project, Zantsi's power base weakened somewhat. Yet it was not the police, an NGO, or political problems that threatened Zantsi. It was his girlfriend. She was getting increasingly upset that Zantsi was neglecting her because he had another girlfriend. In the beginning of November 2005, she called a community meeting and asked the residents to help her solve the problems she had with Zantsi. Because she was angry, she put forward many complaints about her boyfriend. She told everyone that he was having an affair with another woman, that he had stolen a RDP house from its legitimate owners and had given it to her, and that he had misappropriated funds. Allegations such as these revealed that her loyalty towards Zantsi had ended. After this meeting, the ANC suspended Zantsi and also took away a van he had misappropriated.

Unlike in the previous local government elections, there was a contender. Similarly to Shooter, this opponent also used to be affiliated with the Big Five but had distanced himself from them. He had become a candidate for the Universal Party (UP). At least in Indawo Yoxolo, some considered this extremely small party to be a serious threat to the ANC's dominant position. Some wrongly expected that it would attract coloured voters who felt discriminated against by the ANC. Their distrust in the ANC was strengthened after it was discovered that the advisor to Cape Town's mayor, Blackman Ngoro, had written in an editorial on the Website of the Afro Rights Committee in Asia. It stated that Africans are 'culturally superior' to coloureds, who, unless they underwent an 'ideological transformation', would 'die a drunken death'. ${ }^{20}$ The advisor was fired but the confidence with which members of the ANC expressed such racism only fed the feelings of alienation among coloureds. In Indawo Yoxolo, the emergence of the Universal Party created new terrain for political entrepreneurs. Some residents of Indawo Yoxolo believed, however, that if the UP councillor was to win the elections he would immediately leave the UP and join the ANC. With the marginalisation of Zantsi, due to decreasing development funds and an angry girlfriend, this became a likely scenario.

Only a few weeks before the elections, it became clear that Zantsi was still standing as local councillor for Indawo Yoxolo. The ANC had split Indawo Yoxolo into two wards and without publicly readmitting Zantsi to the ANC, Zantsi had become the ANC candidate of the western ward. His UP opponent had left the UP and had become the ANC candidate for the other eastern part of Indawo Yoxolo. ${ }^{21}$ After the elections, Indawo Yoxolo was confronted with two ANC councillors, one for the eastern half, and one for the western half. Very soon, however, residents felt that Zantsi was the councillor for the whole of Indawo Yoxolo and rumour had it that he had intimidated and chased his opponent out of the area. Nonetheless, his power base appeared to be more fragile. Since the elections, however, a very violent youth gang had 'invaded' Indawo Yoxolo. On several occasions they had raped and murdered women who were on their way to the bus or train station. They have also broken into shacks and had attempted to rape a woman in her 
home. For many residents, this gang was far worse than Zantsi and the other project committee members. At the moment it appears that Zantsi is unable to sufficiently intimidate the youth gang for them to leave Indawo Yoxolo.

\section{Arenas of contestation}

If one wishes to examine how successful or dramatic a development project is, one cannot avoid the question 'according to whom?' Surely, in some respects development in Indawo Yoxolo has been successful; there are demarcated plots, sewage systems, electricity, schools, taxi ranks, and recently a shipping container has been placed to house the local police station. ${ }^{22}$ At the same time, there is much dissatisfaction as these development resources were frequently distributed through corruption, while violence and intimidation were at the core of the development process. Development failed to reach its explicit objective to increase empowerment and democracy on a grassroots level and build a secure community.

Even at a superficial glance of the implementation of development policy, it does appear that development increases the authority of the state over its newly recognised citizens, namely Africans who during apartheid were denied their citizenship rights. Local community leaders are co-opted, residents are relocated and categorised and made dependent on social services and housing provided for by the state. In addition, the physical landscape is made legible through clearly demarcated plots with numbers and street names. However, a more intimate examination of the development process brings a much more complex image to the fore in which policy is only one of the many factors of development.

Firstly, even a national presidential development programme such as the RDP relies on the private sector. One could almost speak of the privatisation of development, as private sector companies were at the core of the development of Indawo Yoxolo. Future Dwelling consulted with government officials, several ministries, and local political leaders. They were equally involved in subcontracting to construction companies, in their approach to community leaders, as well as dealing with complaints by residents. Unlike Scott's analysis in Seeing Like a State, development is not a tête-à-tête between the government and its citizens in which private sector companies are passive organisations without their own agendas that the state uses instrumentally (for a state-like private company see Ferguson 2005). In some respects Future Dwelling relied on the Big Five to successfully carry out the projects while their call to residents to present corruption was an indication that they were not as pleased with the Big Five as the opposition believed them to be.

Secondly, the state is terribly dynamic and divided, even after elections in which one party received almost two thirds of the national vote. Concepts such as 'state power' or hegemony tend to downplay these divisions and consequently overemphasises the level of state control (see Li 2005; Moore 1999). How can the Big Five be used instrumentally by the state to achieve its aims when these 
aims are contradictory and contested by diverging governing parties? The provincial ANC appeared to disregard the failure of development in Indawo Yoxolo and instead emphasised party loyalty. But even the Big Five's party loyalty remained precarious. The Big Five was very capable of playing out political conflicts within the ANC, as well as between the ANC and rival parties such as the NP, the UDM, and possibly the UP. Through intimidation and violence they furthermore ensured that no other members of the community could successfully engage in the development process. Furthermore, national and provincial conflicts, such as the end of the Government of National Unity, caused severe political insecurity among the Big Five, which seems to have spurred their use of violence against the residents of Indawo Yoxolo. National, provincial and local conflicts clearly resonated in the Big Five's quest for political manoeuvring.

Thirdly, there is an opposition to development, although this opposition is not acknowledged in the media or development organisations. The opposition has not managed to seriously alter the course of development, nor was it a unified opposition that fought against a unified enemy. It was nonetheless crucial to the political manoeuvring of the Big Five, as well as the increasing level of violence. On several occasions the opposition to the Big Five emerged from the Big Five itself. The enemy was not 'out there' but within the group of temporary allies.

The ANC's RDP project had political ambitions, such as strengthening grassroots democracy and making a brake with the past. If development is an anti-politics machine it is so in our failure to acknowledge the crucial role of national, provincial, or local political struggles. The emphasis on hegemonic powers of the state is in danger of relegating forces that cannot be defined as resistance against the state outside the analysis of development. This case has revealed that violence and conflict are too dynamic to be classified as resistance to the state.

In Indawo Yoxolo two opposing groups continuously develop: as soon as one opposition is destroyed, a new political opponent emerges. Each time the new opposition was a fence sitter, if not an ally to the Big Five. For decades, African political structures, especially in Zulu history, have been characterised as systems of fission and fusion (Gluckman 1971; Kuper 1997:74-77; Shapera 1956). Gluckman (1971:25-26) argues that relationships among the Zulu should be understood within the context of relationships between whites and Zulu. The temporal equilibrium of Zulu social structure could, since colonialism, only be understood by incorporating the role of whites. Shooter's fence sitting in Indawo Yoxolo seems to illustrate Gluckman's analysis of a situation where two unequal groups exist, in which membership could not be changed: ${ }^{23}$

Where there are unequal groups and membership can not be changed ... Dissident members of the superior group may become leaders of these new interest-groups within the inferior. Conversely, some members of the inferior group become interest-groups assisting the superior and standing opposed to the mass of their own group. (Gluckman 1971:48) 
Development can be best understood as an arena of conflict where diverging parties try to establish political security, control over resources, as well as ideological justification for their actions. This arena of conflict knows many emotions, strategies, and social processes that fall outside the dichotomy of compliance versus resistance to development. Instead, it reveals how allies suddenly become rivals, how national and provincial conflicts have severe local consequences, how allies can become friends, and how people try to manage ambiguous socio-political relations.

Initially I was tempted by the analysis as proposed by Scott (1998) and Ferguson (1990) and some of the interpretations here in some ways contradict previous writings in which I did emphasise that development functioned as a kind of rule (see Bähre 2001). Although their analysis of development is extremely valuable, it fails to capture how conflict and violence is at the heart of development. The focus on planning, policy development, language, and conceptual frameworks underlying development, conveys that violence and human suffering is taking place elsewhere, somewhere outside of the realm of development practices. Surely, in a country such as South Africa, with some of the highest murder and rape statistics in the world, development cannot be expected to take place within, or create, a parallel universe in which violence is not crucial. Sadly, fierce struggles over resources, political security, and ideological justification are at the core of development in South Africa.

\section{Notes}

1. I have used pseudonyms and changed insignificant details to guarantee the anonymity of the people, organisations and places.

2. I was unable to find out how exactly the committee was established. Because of the violent dynamics of development, as this study will reveal, it remained difficult to intimately examine the history of some of the social relations of the programme committee.

3. For similar arguments, see Crush 1995; Escobar 1995; Schroeder 1999. The ANC has explicitly recognised development as a means to strengthen citizenships of Africans in a post-apartheid society (ANC 1994:5).

4. See also Crush (1995) and Escobar (1995).

5. See Li (2005:389) on the problematic translation of ethnography for policy purposes by the World Bank.

6. See Thoden van Velzen (1973) for a critical analysis of the big man paradigm and the importance of including political security and control over resources into the analysis. See Van der Linden (1997) on patronage in housing development in Pakistan.

7. Source: Masakhane (1995:4). The structure of the subsidy had an awkward effect on the housing situation of the applicants. Those who received a full subsidy chose a plot with an 'RDP house', as the tiny, concrete one-roomed houses with a corrugated iron roof, one door, and two windows, and a sink were called. Those whose income was too high for a full subsidy would not have enough money for such an RDP house on their plot and instead would build a shack. Many others hoped that they could save enough money in the future to add to the remains of the subsidy in order to build a two-roomed, or maybe even a three-roomed house. This meant that some of the poorest, and those without much hope of improvement in their financial situation, would live in 
the better looking, but not necessarily better built, RDP houses. Those who were financially slightly better off, or expected to be in the future, lived in shacks.

8. For an analysis on the debates and its contribution to post-apartheid housing policy, see Huchzermeyer (2001).

9. The forum consisted of the ANC, Cape Provincial Administration, South African National Civics Organisation (SANCO), Western Cape Regional Services Council, Western Cape United Squatters Association, Cape Town City Council, Western Cape Civics Association, Ikapa Town Council, Umzamo Development Project, Crossroads Town Council, and at a later stage the Pan African Congress (DPC 1994:1).

10. The DPC had secured extra funds from the Provincial Administration of the Western Cape and the Cape Metropolitan Council. This made it possible to raise the RDP subsidy for housing from R15,000, approximately $€ 2200$, to a maximum of R17,250 for each plot and have more money for infrastructure and community facilities (DPC 1996). For further details on the amount of subsidies based on income, see Bähre (2001).

11. See the Local Government Transition Act 209 (1993). See the Provincial Gazette Extraordinary 4943 (1995) for the participating civics in the Western Cape Metropolitan Area.

12. Indawo Yoxolo was not safe for people working for construction companies either. In 1998 a white supervisor, apart from me the only other white person to regularly work in the area, was murdered and robbed of money with which he was about to pay his workers.

13. See Bähre (2006) on my introduction into the field by this group and the consequences it had for this study in general.

14. The local government elections in the Western Cape and KwaZulu Natal (the only provinces where an ANC victory was not certain) were postponed for half a year. In the Western Cape there was a political battle over electoral borders because the way the borders were drawn had important consequences for the election results and tax revenues.

15. On the increase of privatisation in development see Mitchell-Weaver and Manning (1991), and Birdsall and Nellis (2003). For its impact in South Africa see among others Cheru (2001) and Miraftab (2004).

16. See Bähre (2005) for an analysis of the strategies that people and organisations utilise in order to ignore corrupt practices.

17. The information on the proceedings and results of the Commission of Inquiry is from the Commission's confidential report to the ANC, which was passed on to me by an NGO.

18. One of the consequences was that the post of minister of finance, which had been occupied by the NP, became available to the ANC. The new minister of finance (Trevor Manuel) introduced GEAR (the Growth, Employment and Redistribution strategy). GEAR put more emphasis on a macroeconomic restructuring of the economy, creation of jobs, and government responsibility than did the RDP. The strategies of the NP to regain legitimacy in post-apartheid South Africa failed abysmally when the successor to this party, the NNP, abolished itself in April 2005 with a call to its members to join the ANC.

19. These political dynamics are in no way unique and among others Barth (1959:16) and Scott (1972) have analysed some of them. A party that is in power will strive to form a small majority. Such a small coalition, or a majority without a coalition has the advantage that power can be distributed within a smaller faction.

20. Marianne Merten, 'Racist Wars in Western Cape', Mail and Guardian, 22 July 2005, online on http://www.mg.co.za/articlePage.aspx?articleid=246100\&area=/insight/insight_national/

21. The UP election results were very poor. In the Cape Metropolitan Area, they only received one out of the 210 council seats.

22. Recently, the police had to flee the container as officers were under siege. Only later were they able to return to the container.

23. This is the situation that Gluckman (1971) describes, which most closely resembles the political situation in Indawo Yoxolo. 


\section{References}

Abbink, J., De Bruijn, M. and Van Walraven, K. 2003. Rethinking Resistance: Revolt and Violence in African History. Leiden, Boston: Brill.

ANC. 1994. The Reconstruction and Development Programme: A Policy Framework. Johannesburg: Umanyano Publications.

Bähre, Erik. 2001. 'Housing for the Urban Poor in Cape Town: A Post-apartheid Dream or Nightmare?' Global Built Environment Review 1(1): 33-44.

2005. 'How to Ignore Corruption: Reporting the Shortcomings of Development in South Africa'. Current Anthropology 46: 107-113, 117-120.

2006. Money and Violence: Financial Self-help Groups in a South African Township. Leiden: Brill Academic Publishers (forthcoming).

Barth, Fredrik. 1959. 'Segmentary Opposition and the Theory of Games: A Study of Pathan Organization'. Journal of the Royal Anthropological Institute 89: 5-21.

Birdsall, N. and Nellis, J. 2003. 'Winners and Losers: Assessing the Distributional Impact of Privatization'. World Development 31: 1617-1633.

Cheru, F. 2001. 'Overcoming Apartheid's Legacy: The Ascendancy of Neoliberalism in South Africa's Anti-Poverty Strategy'. Third World Quarterly 22: $505-527$.

Crush, J. 1995. Power of Development. London: Routledge.

DPC. 1994. Unpublished Business Plan, November.

DPC. 1996. Development Planning Committee Bulletin 1, February.

Escobar, A. 1995. Encountering Development: The Making and Unmaking of the Third World. Princeton: Princeton University Press.

Ferguson, J. 1990. The Anti-Politics Machine: 'Development', Depolitication and Bureaucratic State Power in Lesotho. Cambridge: Cambridge University Press.

_2005. 'Seeing Like an Oil Company: Space, Security, and Global Capital in Neoliberal Africa'. American Anthropologist 107: 377-382.

Gluckman, Max. 1971. Analysis of a Social Situation in Modern Zululand Volume 28. Manchester: Manchester University Press.

Huchzermeyer, M. 2001. 'Housing for the Poor? Negotiated Housing Policy in South Africa'. Habitat International 25: 303-331.

Jacobs, Ben. 1992. 'Heading for Disaster?' Work in Progress, pp 23-25.

Kessel, Ineke van. 2000. 'Beyond our Wildest Dreams': The United Democratic Front and the Transformation of South Africa. Charlottesville: University Press of Virginia. 
Kuper, Adam. 1997. 'The Academic Frontier: History and Social Anthropology in South Africa'. African Studies (Special Issue: Culture and the Common Place: Anthropological Essays in Honour of David Hammond-Tooke, edited by P. McAllister), pp 69-84.

Li, T.M. 2005. 'Beyond "the State" and Failed Schemes'. American Anthropologist 107: 383-394.

Masakhane. 1995. Home Truths. Issue of Community Newspaper.

Matiwane, Mizana and Walters, Shirley. 1986. 'The Struggle for Democracy: A study of Community Organisations in Greater Cape Town from 1960s to 1985'. Cape Town: Centre for Adult and Continuing Education, University of the Western Cape.

Miraftab, F. 2004. 'Neoliberalism and Casualization of Public Sector Services: The Case of Waste Collection Services in Cape Town, South Africa'. International Journal of Urban and Regional Research 28: 874-892.

Mitchell-Weaver, C. and Manning, B. 1991. 'Public-Private Partnerships in Third World Development: a Conceptual Overview'. Studies in Comparative International Development 26: 45-67.

Moore, D.S. 1999. 'The Crucible of Cultural Politics: Reworking "Development" in Zimbabwe's Eastern Highlands'. American Ethnologist 26: 654-689.

Niksic, G. 2004. 'Difficult but Not Impossible: The ANC's Decentralization Strategy in South Africa'. Development and Change 35(2): 353-374.

Ortner, S.B. 1995. 'Resistance and the Problem of Ethnographic Refusal'. Comparative Studies in Society and History 37: 173-193.

Scott, J.C. 1972. Comparative Political Corruption. London: Prentice-Hall.

1998. Seeing Like a State: How Certain Schemes to Improve the Human Condition have Failed. New Haven and London: Yale University Press.

Schroeder, R.A. 1999. 'Community, Forestry and Conditionality in The Gambia'. Africa 69: $1-22$.

Seekings, Jeremy. 1992. 'Civic Organisations in South African Townships'. South African Review 6: 216-238.

1996. 'The Decline of South Africa's Civic Organisations, 1990-1996'. Critical Sociology 22(3): 135-157.

Shapera, J. 1956. Government and Politics in Tribal Societies. London: Watts.

Thoden van Velzen, H.U.E. 1973. 'Robinson Crusoe and Friday: Strength and Weakness of the Big Man Paradigm'. Man 8: 592-612.

Van der Linden, Jan. 1997. 'On Popular Participation in a Culture of Patronage: Patrons and Grassroots Organization in a Sites and Services Project in Hyderabad, Pakistan'. Environment and Urbanization 9(1): 81-90. 